\title{
EFL Women-Learners Construction of the Discourse of Egalitarianism and Knowledge in Online-Talk-in-Interaction
}

\section{Construcción de discursos de equidad y conocimiento en interacciones en línea de mujeres estudiantes de inglés}

\author{
Adriana Castañeda \\ English Language Teacher \\ Centro Colombo Americano \\ Bogotá - Colombia \\ E-mail: adricalo29@gmail.com
}

Received: 24 - Aug - 11 / Accepted: 23- May - 12

\begin{abstract}
This research project sets out a 'synthetic approach' (Wetherell, 1998) to discourse analysis by combining elements of conversational analysis and critical discourse analysis. I explain the construction of a discourse that emerged from seven EFL women-learners online chat discussions around literature and how this discourse informs language as a socialization process. The findings suggest that while talking online, the language learning experience of these women-learners is intersected by what I labeled as the discourse of egalitarian-knowledgeable learners. It appears that through the enactment of this discourse, the students identified each other as equal status partners through conversational moves of solidarity, solicited help and repairs in miscommunication. The construction of such discourse shows that the language socialization process worked as an apprenticeship model. This project suggests that the seven EFL women learners, who participated in this research, invested in their language learning process as a result of the co-management of their power relationships as I will portray along the document by tracing the discourse and giving a polyphonic interpretation of the data.
\end{abstract}

Key words: Poststructuralist Discourse Analysis in online interaction, Discourse, Language learners, Language Socialization.

\section{RESUMEN}

Esta investigación expone un 'enfoque sintético' (Wetherell, 1998) de análisis discursivo mediante la combinación de elementos de análisis conversacional y análisis crítico del discurso. Se prentende mostrar la construcción de un discurso que emerge de la discusión sobre textos literarios que realizan siete estudiantes mujeres en un servicio de mensajería en línea y como este discurso puede dar cuenta del proceso de socialización en lengua extranjera. Los resultados sugieren que mientras se conversa en línea, la experiencia de aprendizaje de estas mujeres-aprendices esta entremezclada con el discurso que he denominado "aprendices igualitarias y sabedoras". Se observa que a través de la construcción de este discurso, las estudiantes se identificaron mutuamente como compañeras de igual estatus a través de movimientos conversacionales de solidaridad, pedida de ayuda y clarificaciones en la comunicación. La construcción de dicho discurso muestra que el proceso de socialización funcionó como un modelo de "aprendizaje". Este proyecto sugiere que el proceso de aprendizaje se produjo a causa del manejo conjunto de las relaciones de poder, como se mostrará a lo largo del documento rastreando el discurso y mediante la interpretación polifónica de los datos.

Palabras claves: Análisis poststructuralista del discurso en interacción virtual, Aprendices de lengua, socialización

* This research study was done using Portal Interactivo ETB en Bosa Metrovivienda in an English course taught during two years. It was carried out as a requirement to obtain the degree in M.A. in Applied Linguistics to TEFL at Universidad Distrital Francisco Jose de Caldas. 


\section{Introduction}

From a poststructuralist perspective to foreign language research, Norton (2000) suggests that "teachers need to understand how opportunities to practice the language are socially structured in both formal and informal sites of language learning." (p.16) Thus, by deconstructing actual chunks of talk it is possible to understand how language socialization processes and opportunities to practice the language occur in a context where English is not the mainstream language and how these opportunities are intersected by discourses manifested through in situ identities. This article reports on a poststructuralist discourse analysis carried out to online talk-in-interaction of seven EFL women learners who discussed literature through Instant Messaging (IM). The objective of the study was to identify discourses through which EFL women learners located in online talk and how the discourse could inform online foreign language socialization.

\section{Poststructuralism and Language Socialization}

Poststructuralism in the area of Applied Linguistics is an umbrella term used to describe an epistemology interested in theorizing the intersections between social phenomena and learning (Pennycook, 2004). This epistemological framework seeks to reveal how the processes of learning other languages are intersected by the construction, maintenance, resistance, reproduction or display of social structures when people develop social relationships with those with whom they are learning.

Within poststructuralism, the results of second and foreign language learning are intersected by the different subject positions of gender, class, race or power that are available, constructed or adopted discursively within talk. These subject positionings build the way people are recognized by others and the way others recognize them discursively. Within the poststructuralist framework, language is considered "a cultural capital that allows access to symbolic and material resources" (Pavlenko, 2002, p. 283). Such access is intersected by the very complex power relations framed within talk. Thus, the study of snippets of talk-in-interaction may shed light on the way power is allocated within talk, how identities are constructed in situ, and how learners actually gain access to the language as a symbolic capital in order to be able to socialize in the foreign language.

Following Norton (2000) it is worth analyzing how relations of power in real social worlds influence interaction between second language learners and target language speakers. However, in a context where English is a foreign language, it is worth analyzing how such power relations, subject positions, and socialization processes take place with and among learners. In fact, while there are studies that have explored the intersection of language, power and identity, taking language as a socialization process (e.g. Norton, 2000; Miller, 2003), they have been mostly carried out in countries where English is the mainstream language (Moore, 2008). Therefore, I consider we are in need of studies that deconstruct language socialization experiences in a context in which English is used, appropriated and approached differently from English as a Second Language (ESL) settings. Language socialization literature suggests that socialization is referred to as the various processes through which "people gain communicative competence and membership," through participation in talk (Moore, 2008 p. 175) Thus, two aspects for teacher-researchers to address would be firstly, how EFL learners construct interaction in a context where the target language is appropriated through instruction. And second, how they gain communicative competence and membership 
with other learners through their own cultural paths to communicative competence.

\section{Poststructuralist Discourse Analysis (PDA), Power, Language and Identity}

PDA is a type of discourse study Methodologically speaking it takes elements of conversational analysis (CA) such as the analysis of the architectural organization of a conversation and elements of critical discourse analysis (CDA) like the examination of verbs, nouns or adjectives with the objective to understand how social actors are backgrounded or foregrounded as social actors in a text (Seedhouse, 2004; Sunderland 2002). The analyst takes the position of uncertainty about absolute truths towards knowledge; meaning is context-bound, provisional and constructed. The analyst may observe how participants of talk experience power. Power, for Norton (2000) refers to the "socially constructed relations among individuals, institutions and communities through which symbolic resources (e.g. language) in a society are produced, distributed and validated" (p. 7).

Thus power is not fixed. It fluctuates and that locates participants of interaction in powerful or powerless positions within talk (Baxter, 2003, Sunderland, 2006). My choice for post-structuralist discourse analysis relates to my understanding of language and identity as social constructions shaped by race, class, gender etc considering claims by Pavlenko (2002) and Norton (2000). In the same train of poststructuralist thought, Weedon (1987) conceptualized language as "the place where actual and possible forms of social organization and their likely social and political consequences are defined and contested" (p. 21).

\section{Language Socialization and Instant Messaging}

Along with a conceptualization of identity, power and language, there is as well an understanding of the language learning processes from the poststructuralist perspective. Language learning is conceptualized as a social construction because as suggested in Bakhtin (1981, cited in Mckinney and Norton, 2004) second language learning is not "a process of neutral internalization of rules, vocabulary of standard language but a matter of appropriating the words of others." (p. 117). As a matter of fact, language learning is a process of socialization. Here I conceive of language socialization as a theoretical base for understanding how through various cultural ways people gain communicative competence, membership and legitimacy in a group. (Moore, 2008; Duff, 2007) Indeed, language as socialization has shown interesting insights concerning how L2 speakers achieve validation or exclusion as group members (Toohey, 2001). As well, how friendship networks help L2 speakers achieve participation in mainstream language practices (Willet, 1995).

The analysis of socialization dates back to the pioneering work of Ochs (1993) who studied how middle class American children socialized during mealtime in order to understand how they were introduced to the understanding of social identity. Interestingly, she suggests that children participated in a co-constructed narrative in which the family reported the day's events. By means of co-authoring the narratives, the children were socialized with the idea of the importance of family. However, in the area of EFL, there seems to be a small number of studies considering the phenomenon of socialization. (Moore, 2008) An ethnographic study done by Duff (1995) studied socialization processes of FL classrooms in post Soviet Hungary. Duff found that traditional recitation practices in the high school classrooms were being left aside by more interactional language practices. These findings are not only meaningful in the context of FL learning but also as an account of societal changes to 
more democratic practices in the Post Soviet countries. Similarly, another study concerning how cultural meanings are appropriated is the case of online socialization conducted by Lam (2004). She explored the discursive and social practices of a bilingual chat as a socialization context for two Chinese immigrants who wanted to be fluent in English. By analyzing observations, discourse and interviews, the author concludes that as the Chinese immigrants used English and Cantonese in their interaction, they were building their affiliations as bilingual speakers. While having trouble interacting with school peers, the participants created bonds with peers of their same origin through the chat room. Lam (2004) concludes that by using Cantonese discursive markers (these are particles that help participants interpret messages) into English conversations, the participants developed empathy with each other. Likewise, the Romanized use of Cantonese honorific suffixes communicated social meanings such as gender markers, affection and respect or provided the interaction specific tones in the conversation.

As seen in the above mentioned studies, the major concern about language as a socialization process deals with what Moore (2008) describes as an interest in the "community norms, preferences and expectations regarding language competence, and how they are locally enacted and negotiated" (p. 178). Similarly, through these studies (Duff, 1995; Lam, 2004) we can see how the participants in those interactions develop multiple affiliations or identities.

\section{The Case of Research Concerning Instant Messaging (IM)}

To my knowledge, studies about instant messaging have mostly focused on gender differences in linguistic traits of instant messaging talk (Baron, 2004), use of institutionallyrelated instant messaging discussions (Kinzie et al, 2005), linguistic comparison of instant messaging (Ling and Baron, 2007), state of the art on Synchronous Computer Mediated Communication taking language from a modernist perspective by Kawase (2006), and the seminal $\mathrm{PhD}$ dissertations of adolescent girls and boys use of instant messaging, (IM hereafter) (Thiel, 2007, Jacobs, 2005, Lam, 2009). On grounds of space I will comment on the results of research which deals with a socio-cultural perspective of this literacy practice.

To start with, IM has been conceptualized as a way of almost immediate communication through networked computers. The software consists of a list of contacts; icons that show the user's status and a virtual forum for the exchange to take place (Jacobs, 2008). Similarly, other studies on the use of computer mediated communication for learning purposes (Okuyama, 2005; Hampel E Hauck, 2006; Kawase, 2006; Albright et al, 2002) agree that synchronous communication looks like face to face interaction. Users may take advantage of visual cues (emoticons and winks) to some extent replace the lack of physical presence. Also, their interactions frequently experience troublesome turn-taking. However, closeness may be promoted even considering the lack of physical presence by means of clarifications and explanations which are possible due to the real time nature of communication (Doering et al, 2008).

From a linguistic perspective, Charles (2008) affirms that IM is a "rather refined type of literacy for its clever economy of words and nuanced expressiveness." (p. 20) yet, such conceptualization may hold true depending on the context. Considering Lankshear and Knobel's (2006) understanding of literacy, it can be said that the IM discursive practices are a socially accepted means of "generating, communicating and negotiating meaningful content" (p. 64) through, in this case, electronic text. However, it would be impossible to generalize the type of 
linguistic characteristics found in IM texts, if we are to consider EFL learners use of it. This argument is inferred from Jacobs (2008) acknowledgment that research on IM is mainly a reflection on the type of participation of the middle class American culture in instant messaging literacy practices.

On the other hand, a poststructuralist conceptualization of instant messaging should also include the idea that people construct their identity in the very act of talk. In that sense, IM represents a written record that resembles talkin-interaction for the synchronic nature of the interaction and it is considered a site of identity negotiation with others because beliefs and cultural knowledge emerge in such interaction (Thiel, 2007). Thus, instant messaging greatly describes the locations within discourses of the community members in which IM is used.

As for the study of instant messaging, Lewis and Fabos (2005) identified the kind of social subjects and social identities seven middle-class youngsters constructed through their IM use. They concluded that IM was used to maintain social relationships on and off-line. They also found that the linguistic features of the interactions showed that participants were aware of what words to select, what tone to use, what matters they could deal with so that their conversations were interesting. The research participants had clear purposes in the use of metaphors and awareness of style in accordance with whom they were talking. They were also spelling-conscious, skillful at multi-tasking (scanning across different windows) and at having lively interactions.

Similarly, Jacobs (2005) analyzed the IM literacy practices of middle class youth (a girl and her friends). The author explored the meaning of the language conventions used in relation to various discourse communities. The research participant was able to design a hybrid form of texts that both "enacted and countered dominant ideologies regarding standard orthographies" (p. 252). By means of critical discourse analysis Jacobs (2005) constructed her participant as a text consumer, producer and distributor. Besides, she noticed that the use of IM changed over the two year period of observation; first the participant used IM mainly to lessen boredom; by the end of the study the participant's emphasis was on maintaining contact with a particular group of people in order to gather and distribute information. She also found the use of standard and non-standard spelling depending on the aim of the IM activity.

Also Lam (2009) makes the case of how a migrant Chinese girl integrated digital practices in her life and the kind of socialization that occurred in different IM discourse communities through which she participated. She described how the migrant Chinese used IM to negotiate her social relations within diverse linguistic and cultural communities. Lam identified how different linguistic resources were used in order to display the girls' online participation in local American IM youth culture and transnational Shanghainese and Hongkonese IM relations with relatives and friends. The author concludes that through the participant's development and maintenance of membership in different "lifeworlds", she wished to develop a literate inventory that could allow her succeed in multiple discursive communities. Lifeworlds, Lam (2009) explains, refer to the "spaces for community life where local and specific meanings can be made" (p. 386). What the author suggests is that by participating in the chats of different discourse communities, the research participant was able to grasp knowledge of how to belong to the transnational communities and the local communities to which she was having access to. Her second finding is that by using a mixed variety of English that incorporated standard and non-standard orthography along with African American Vernacular English and 
hip hop language, the Chinese immigrant was "constructing an English speaking voice for herself" (p. 387). This contributed to creating bounds with Asian Americans and positioning herself out of the "new immigrant" status and eventually being able to interact more with local school peers. Finally, the author suggests that by using a mixed variety of Cantonese and Shanghainese, the girl could maintain her social bounds with her hometown.

Up to here, some theoretical tenets that scaffold this study have been discussed. So far it has been said that instant messaging is a type of computer mediated communication through which people may generate and communicate meaningful content. Furthermore, it was also conceptualized as a site of identity construction and identity negotiation. It is relevant to mention that such characteristics make that interaction through instant messaging has a great potential as a discursive practice in the process of language learning. In fact, from a pedagogical perspective, Fernández-García and Martínez-Arbelais (2002) concluded that by participating in chat interactions Spanish learners were able to successfully resolve communication breakdowns through strategies such as translation and echoing of unfamiliar lexical items to prompt clarifications of meaning in the discussion of literature in Spanish. I will move into explaining the research design and findings of this study.

\section{Method}

This study intended to trace the discourses through which a group of women learners subject-positioned in online interaction and how the construction of discourses could inform language as a socialization process consistent with the theoretical claims that I have described along this document, this research is a Discourse Analysis (DA) study framed within a poststructuralist perspective through which the analyst acknowledges different perspectives. Here I am following Wetherell's argument of having a "synthetic approach" to discourse analysis. I took advantage of conversational analysis for its interest in the context-situated nature of interaction along with some elements of critical discourse analysis for its interest in how discourses are displayed, constructed, negotiated and the like. (Wetherell, 1998 in Baxter, 2003) In the chart below, I illustrate the different layers of analysis through which I found the discourse of egalitarianism and knowledge in which a group of EFL women learners constructed their language learning experience.

SINTHETIC APPOACH TO DISCOURSE ANALYSIS (WHETHERELL, 1998)

CONVERSATIONAL ANALYSIS (SEED HOUSE, 2004)

METHODOLOGICAL ELEMENTS OF CRITICAL DISCOURSE ANALYSIS (SUNDERLAND, 2002)

Chart 1: Synthetic Approach to Discourse Analysis

Methodologically speaking, Discourse analysis is a conceptualization of social life, which consists of epistemological elements (ways of thinking about discourse) and methodological considerations (ways of treating discourse as data). In this view, language is considered the means through which people reach social ends and talk is particularly seen as constitutive of reality. (Wood and Kroger, 2000). Conversational Analysis (CA) is a method to understand stances of naturally occurring talk. It attempts to describe how people say what they say, how social actions are accomplished through talk, how interactants achieve intersubjectivity or understanding (Seedhouse, 2004). To warrant that the CA makes sense and is trustworthy. I followed the four steps proposed in Seedhouse, namely: unmotivated looking or being open to new phenomena. Then, I applied inductive analysis for identifying a "candidate phenomenon" and stances of it. Next, I established regularities and patterns in relation to occurrences of the phenomena to see how they were methodically produced and oriented 
by the participants; finally I explained the emic sense of the phenomena. (Seedhouse, 2004, p. 39) All these steps were carried out by means of understanding the interactional organization of the sequences of online talk. This means that how the adjacency pair, the preference organization, the turn-taking and the phenomenon of repair of miscommunication were considered in order to account for the steps described above.

On the other hand, Critical Discourse Analysis focuses on understanding the workings of the social world, considering people as belonging to a specific socio-historical context and texts, either written or spoken, as intersected by other texts and different social practices. Benwell and Stokoe (2006) explain that "CDA has an interest in the role of language in the transmission of knowledge, the consolidation of hegemonic discourses... and much work in CDA implicitly treats identities as effects of the ideological work performed by discourse" (p. 105). As for the use of CDA I applied Sunderland's methodology (2004) which focuses on "linguistic traces" of discourses specifically through the participants' use of specific grammatical and lexical choices and sometimes re-occurrences (repetitions) of these linguistic items in order to represent the world in a particular way. Consequently, I focused on specific verbs, nouns and adjectives that served the purposes of including, excluding, backgrounding or foregrounding social actors in the conversations.

The participants selected for this study were those ones who freely accepted to send their chat logs to my email. Hence, the participants were selected upon convenience (Merriam, 1998) and the analysis was carried out to a set of four months of conversations (from January-April 2009) collected on a weekly basis. In all of the cases learners were given a consent form that ensured confidentiality and freedom to drop out when they considered. My role as a researcher was that of participant observer and for the characteristics of the analysis the data were looked from both an emic (CA) and an etic perspective (CDA). After the analysis was done, my interpretations as a researcher were shared, compared and expanded with those of the participants in order to have a polyphonic interpretation via the use of interviews.

\section{Description of the Context and Participants}

Seven women between 26 and 42 years of age and various occupations (students, housewives, self-employed) attended the English class for about two years. They started the course as beginner learners and upon registration they reported having a basic English level. The learners had a three-hour English class on a weekly basis which took place at a "Portal Interactivo". This is a classroom equipped with computers and internet sponsored by Empresa de Teléfonos de Bogotá in Metrovivienda (a neighborhood located in the south of Bogotá).

In order to understand the micro-politics of this classroom, I should clarify that both the students and I, the teacher, agreed on participating on this class because we all shared a passion for learning the English language. The lessons were aimed at developing the four skills. We followed some English textbooks and the class was framed within the task-based approach to language learning. This means that by carrying out different activities we tried to achieve real life communication. Students could take advantage of the web several tools for social or educational purposes (e.g., emailing people from different countries to learn customs, using online software to practice pronunciation, chatting with classmates about a topic or writing opinion essays in the class' wiki). Critical thinking and critical literacy abilities were promoted through the reading of books in English and Spanish and self-evaluation, self-reflection, and feedback 
on performance were the means of evaluating learners' outcomes.

Along the course, learners read the readerfriendly versions of some classics of the English literature such as "Dr. Jekyll and Mr. Hide", "Hamlet", "Oliver Twist", "The Tragedy of Dr. Faustus" and others. The reasons to include reading as part of the class were threefold. On the one hand, I am convinced that reading enhances language learning for learners get some written and oral input (through the text and the audio of the books). On the other hand, the discursive practices around readings generate some reflection through critical literacy activities such as discussion in Spanish, or other related activities like seeing a play about the book. Finally, including reading as a systematic part of the class also attempted to cater for students' likes.

\section{Findings}

\section{Constructing the Discourse of Egalitarian Knowledgeable Learners}

There are various excerpts of the women learners' online-talk-in-interaction which evidence that the research participants positioned as egalitarian learners performing a high academic status. When saying egalitarian-knowledgeable learners I am referring to them in two ways. On the one hand, with the word "egalitarian" I mean a co-constructed status of "equal language learners'. On the other hand, with the word "knowledgeable" I refer to the way the women learners constructed their academic status. The expression academic status is referred in Cohen (1994) as "the most powerful of the statuses characteristic in the classroom because of its obvious relevance to classroom activities" ( $p$. 101). The women learners constructed their academic status by being aware of their learning processes. They reflected on grammar issues, meaning precision, and displayed their strategies to cope with unfamiliar words. In such a way they constructed themselves as knowledgeable English language learners.

Besides, it can be argued that through moves such as repairs (interactional resources to achieve that interactants clarify or correct previous contributions, Nakamura, 2008) learners implicitly positioned themselves as egalitarian knowledgeable learners. As described in the excerpts below there are (a) repairs in accuracy combined with face-saving strategies, (b) repairs in meaning and (c) traces of collaborative talk. Through these conversational moves, (Sinclair and Coulthard, 1975) the learners positioned themselves as articulate knowers, (CastañedaPeña, 2008) but not necessarily as intellectually superior to their own conversational partners. What I observed is that while acknowledging their linguistic mistakes or displaying carefulness and meaning precision, learners' comments were also framed in an attitude of equality as seen in the descriptive analysis of repairs at the linguistic and meaning level below.

In a similar vein, the status of egalitarian learners can also be portrayed through some face-saving moves. Shin (2006) has described "face-saving" as "an interactional norm within group dynamics" (p. 71) in which participants can wave between positive and negative face by being respectful and polite or on the contrary being pride or self-sufficient. In the present data, several conversations show that learners do not embarrass their conversational partners for making a mistake, nor do they seem to show self-sufficiency. On the contrary, they praise, show solidarity and respect.

Example 1: The "you calm, we are learning" talk

In the next IM conversation, learners Mary and Lesly (not their real names) are discussing chapter three of "Oliver Twist" by Dickens (1837). 
In this chapter the author tells Oliver's adventures and difficulties attempting to arrive to London. Oliver is taken by another child to the house of Fagin, a thief who gave him shelter. (Lines highlighted in yellow account for the stances of the event of conversational repair)

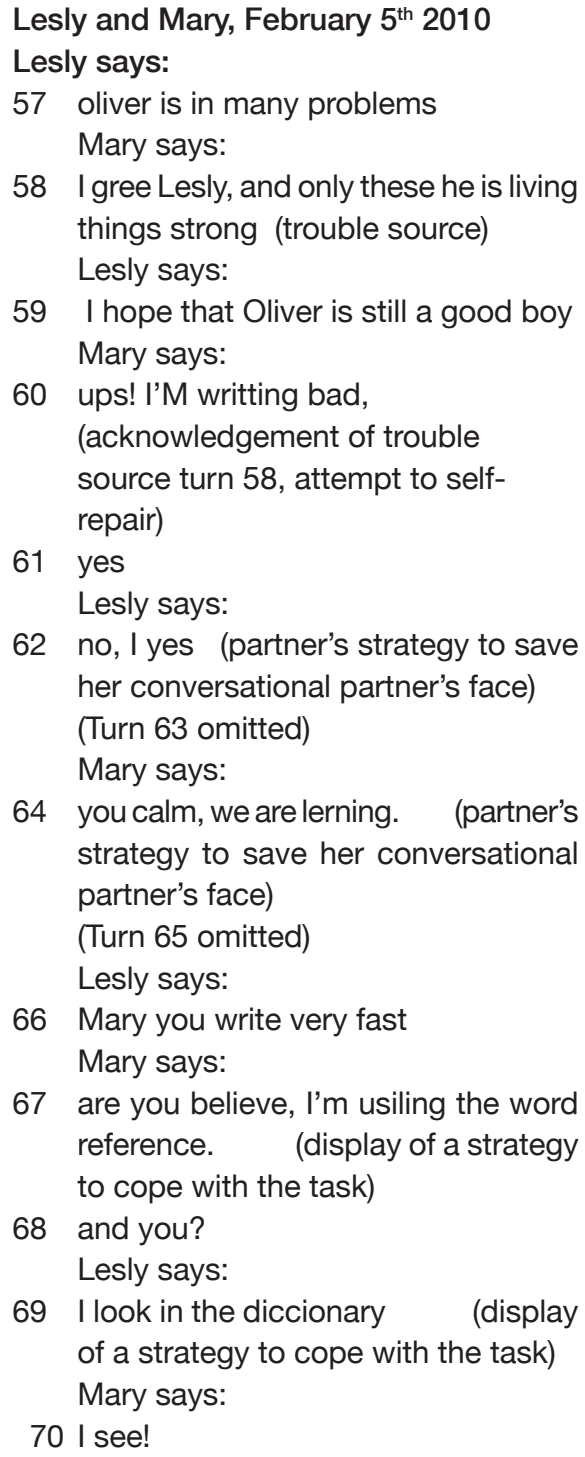

Lesly explains that Oliver is in trouble (57). Mary agrees with Lesly and she adds that Oliver is living strong experiences (58). Lesly expresses that she expects Oliver to still be a good boy (59). Mary starts the new turn (60) with the exclamation "oops" in its Spanish phonetics, in order to acknowledge she has mistyped her "I agree" of turn 58 and perhaps attempting to self-repair or solve a possible cause of miscommunication. As well she adds the interjection "yes" to agree with what Lesly just explained in turn 59 (61). Then, Lesly uses the interjection "no" in order to contradict Mary in that she is writing badly; she uses Spanish grammar for adding an emphasis ("I yes") in order to explain that it is her who is writing the wrong way (62) thus, signaling solidarity as a face-saving move not to embarrass Mary.

Next Mary reacts to Lesly's deference in turn 62 and asks Lesly to take it easy as they are learning (64). Lesly then comments on Mary's quick responses by telling her that she writes very fast (66) Mary asks her "are you believe?" meaning "do you think so?", "Really?" Later she adds that she is using the "wordreference dictionary" possibly explaining to Lesly why she is writing "so fast". She keeps the conversation going by saying "and you?" (67). Lesly answers that she is looking in the dictionary (68) the adjacency pair finishes when Mary says "I see" to conclude (69)

The "you calm we are learning" talk exemplifies a case of a repair in accuracy combined with the face saving strategy of sympathy. Turns $60,62,64,67$ and 69 are particularly enlightening for the discussion on learners' implicit moves towards a discourse of egalitarian learners. We can see that through the acknowledgement of the need for accuracy as in "ups! I'M writting bad"; through conversational moves to show sympathy or to save a partner's face (Shin 2006) for example: "you calm, we are lerning" as well as through the display of strategies to cope with the task: "I'm usiling the word reference", "I look in the dictionary" learners try to negotiate what in mainstream SLA research is called "output" (Swain, 1985). As mentioned in the research design, in order to 
have a polyphonic interpretation of data learners were asked to read the analysis and propose their own ideas about it in an interview. Thus, when Mary was asked to explain what she thought was occurring in the talk and if she agreed with these interpretations, she explained: "Yes, really in our talk we show ourselves supportive and also we share tools and knowledge". (Mary)

In a way, these learners could be seen as actors who are struggling to get things done with their emerging language competence (Roberts, 2000) while displaying subject positions of equal status learners. This is actually suggested by Lesly when she was asked to interpret the conversation of example one as seen below:

- "I try to be sure of what I'm saying, no matter the tools that we use for learning. We try to have a good friendship because we are learning" (Lesly)

What Lesly's comment suggests is that indeed being competent in the language is important for her. It also appears that friendship may have a relationship with the act of learning in that she constructs her learning experience based on the status of egalitarianism and bonds of friendship.

\section{Example 2: The "I don't understand" talk.}

In the next conversation, Lesly and Rosa are talking about a chapter called "The Crime" in which Dickens (1837) describes the way Oliver is pushed to help Fagin and Sikes (the thieves with whom Oliver lived) to steal a country house. The boy is badly injured.

Lesly and Rosa, February $27^{\text {th }} 2010$

Lesly says:

$41 \mathrm{I}$ jope that Oliver be a boy lucky in the

life (trouble source)

(Turns 42 and 43 omitted)

Rosa says:

44 what is jope?

(acknowledgement of a trouble source)
45 idont' understand

Lesly says:

46 Rosa, I tell you that The Mr. Brownlow

was for Oliver like a father (actual repair)

47 and he don't forget to Oliver, he got for

all the world,

Rosa says:

48 yes, I agree

In this IM log, we see that Lesly expresses that she hopes Oliver be a lucky boy in life (41). Rosa asks "what is jope" (44) acknowledging that turn 41 represents a trouble source of understanding; she seems not to understand what Lesly means. In fact, Rosa asks for clarification saying that she does not understand (45). Then Lesly tries to rephrase what she just said so that what seems to be a misunderstanding at the lexical level can be clarified. Lesly modifies her speech and explains that Mr. Brownlow behaved like a father to Oliver (46) and that he does not forget about him (47). Although it is not made explicit whether Rosa clarified the misunderstanding it appears that she got Lesly's idea and this is seen through her agreement move: "yes, I agree" (48).

What does the "I don't understand" talk reveal about the "knowledgeable learners discourse"? Turns 44 and 45 (What is jope, I don't undertand) display a repair consisting possibly of a "request for definition, translation or explanation" (Cho E Larke, 2010) which shows Rosa's engagement with the conversation in order to produce meaningful participation. For Hegedus $\&$ Penuel (2008, p. 175) "talk is an arena for displaying competence and expertise". Thus, it is Rosa's effort to locate herself as a competent speaker which moves her towards the use of a repair that leads her move into expressing her own views.

Once Rosa was asked about her opinion on what was happening in the talk, she agreed with the previous interpretation and explained that: "unknown words change the meaning of phrases and it's better to ask in order to be able to continue 
and understand the talk" (Rosa)

Hence, this response also leads us reconstruct Rosa's attempt to hold a high academic status especially when she says "it's better to ask in order to continue the talk". From this phrase it can be inferred that she not only wants to make a meaningful contribution to her talks but also to make sure what unknown words mean.

Similarly, the chat talk shows how Lesly tried to cooperate with her conversational partner in: "Rosa, I tell you that Mr. Brownlow was for Oliver like a father..." With such phrase, Lesly signals solidarity towards Rosa's attempt to get the meaning across and rephrases her complete turn in order to help Rosa understand.

From a social perspective applied to language studies, we could argue that Rosa's linguistic signaling "idon't understand" (45) as well as the shared cultural and social background of egalitarian learners worked to produce involvement from Lesly's side eventually helping Rosa solve a miscommunication problem (Roberts, 2000). From a language socialization perspective, it could be interpreted that Rosa needed to be socialized into specific lexical items so that she could understand a situated meaning. Consequently, she resorted to a repair in order to be socialized in a specific language item.

From a SLA perspective, the acts of repair in talk push the learner to modify her output (Swain, 1985). What we saw in the previous encounter is that a clarification request made by Rosa ("what is jope I don't undertand") pushed Lesly to rephrase her turn, perhaps allowing her to notice her lexical pitfall ("I jope that Oliver...") or at least the need to resort to new language to express the same idea.

Example 3: "I write the words bad but, you are [under]stand"

In the next IM talk, learners are discussing the chapter of "Oliver Twist" called "Nancy's secret". Here Dickens (1837) describes that Monks, Oliver's half-brother, meets Mr. Bumble, the master of the workhouse where Oliver was born.

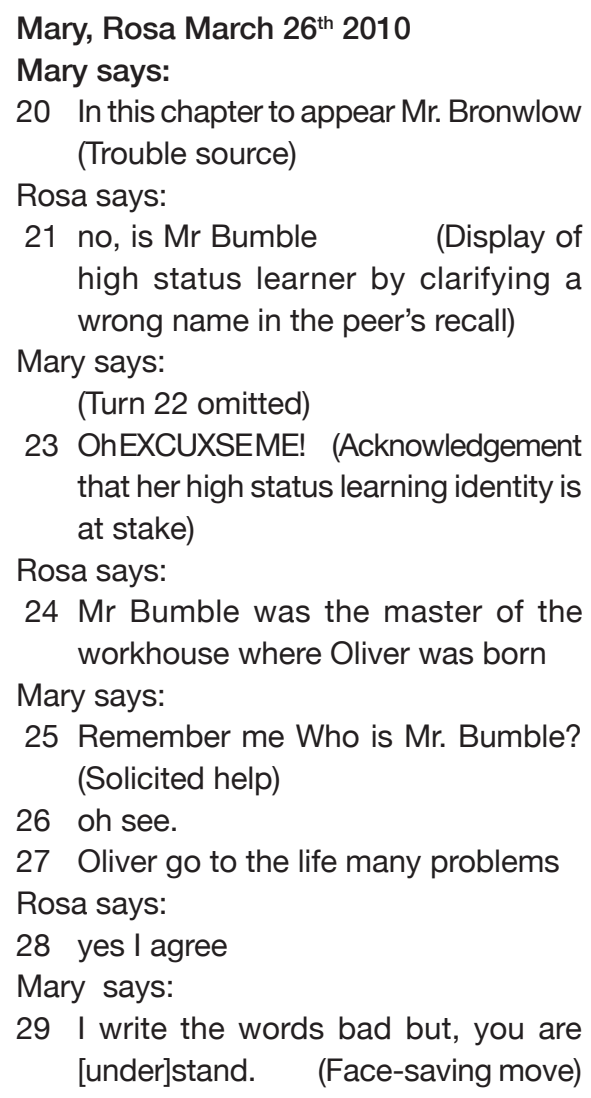

Mary comments that Mr. Brownlow takes part in the chapter (20). However, Rosa corrects Mary saying that it is not him but Mr. Bumble (21). Here we see a first attempt of Rosa to develop her subject position of high academic status learner constructing herself as a knowledgeable language learner.

Mary apologizes for not using the appropriate name of the new character (23). Rosa contextualizes Mary on who Mr. Bumble is, explaining he was the master of the workhouse where Oliver was born (24). It appears as if both students were typing at the same time. However, it is Rosa's message which appears first on the 
screen because Mary attempts to remember who this character is by asking Rosa to remind her (25). She adds the turn "Oh see" to mean she got the idea, perhaps after remembering herself the story episodes (26). She adds an evaluation of the whole situation explaining that Oliver has much trouble in his life (27). Rosa agrees with her (28). Finally Mary comments that she is writing badly but still Rosa understands what she means (29).

The case of the "I write the words bad but, you are [under]stand" evidences once more the discourse of egalitarian-knowledgeable learners in certain moments of the talk. Rosa, for example, held the subject position of a more articulate knower (Castañeda-Peña, 2008) in the talk by correcting mistaken information displayed by Mary ("no, is Mr Bumble"). Such a status of knowledgeable learner is threatened in Mary's own moves and she appeared to feel embarrassed about not addressing correct information $(\mathrm{OH}$, EXCUSE ME!). However, while attempting to acknowledge more expertise on Rosa's side ("Remember me Who is Mr. Bumble?") ("I write the words bad but, you are [under]stand"), Mary tried to reconfigure her academic status of knowledgeable learner.

From a language socialization perspective it could be also argued that learning is taking place here by means of socialization as "an apprenticeship model" (Roberts, 2000). In example 3, the more expert student socialized the less expert one into the meanings of the text in order for her to be able to continue the conversation.

Once these above-stated interpretations were shown to the participants in follow-up interviews, Mary and Rosa highlighted the fact that they get on very well and there's solidarity, help and comprehension in the learner-to-learner relationship. What is more, Mary acknowledged the influence of gender in the learning process as we will see below:

- "Yes of course, there is understanding because Mary and I get on really well in terms of the class and it's easy for us to agree...besides, we almost always work together, we identify (with each other) in the class" (Rosa)

- "Independently of what person I talk to, there is always understanding, solidarity, help and comprehension. This happens because in general terms we get on well and we fairly know each other. I think it's because we are a few students and we are all women" (Mary)

So far, I have shown examples of a discourse towards how learners articulated themselves as knowledgeable people in an egalitarian sense. Within poststructural theory, one core question is that of power: How people experience power in stances of learning environments (Baxter, 2002; Castañeda-Peña, 2008a, 2008b, Norton, 1995). It seems that in this study that power has been co-managed by these learners in an attempt to cope with a language task while negotiating their own learners' identities. This finding is of interest to a poststructuralist view of language learning. What we can see through the data is that the co-management of power translated into an atmosphere of equality and respect. Such power co-management allowed that interactionally speaking language learners could have even access to practice the foreign language. In other words, taking Norton's theory of investment (1995) it could be said that the women learners' construction of egalitarian relationships allowed them to invest in their language learning. This means that, the social and historical relationships of the women and the foreign language were coached by the support of other learners socially constructing a motivation to practice the FL.

\section{Discussion}

The Construction of Discourses and Social Identities in EFL Online Talk 
This research held an interest in the construction of discourse and how it could inform foreign language socialization. The data suggest one main discourse which I will explain below.

First, it is evidenced that while discussing literature online, women learners displayed academic language-learner identities of equal status partners. This is achieved by helping each other get their messages across in situations in which they may lack a higher linguistic competence as enacted through the discourse of egalitarian knowledgeable learners. Through moves of solidarity, solicited help and repairs (see chart below) the seven EFL language learners socialized each other into lexical items or meaning understanding. In such a way, socialization worked as an apprenticeship model (Roberts, 2000) in which the more expert language learners helped their less expert conversational partners to get meanings across.

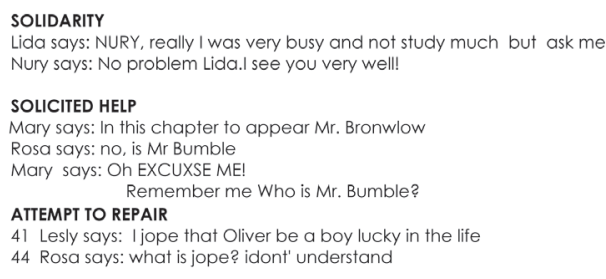

Chart 2. Conversational Strategies that enact the discourse of Egalitarian-Knowledgeable learners

Chart 2 exemplifies how conversational strategies are used to draw on the discourse of egalitarian knowledgeable learners. This means for example, that when Nury says 'No problem Lida. I see you very well', she is appealing to the solidarity move not only to support what has been said by Lida but to help her (reconstruct herself as a good language learner despite her statement about being busy to take the time to study). This is also apparent when soliciting help moves occur. Chart 2 also exemplifies this move between Mary and Rosa. It is Mary who ends up making such a move to clarify regarding the reading, the nature of one of the characters. When this is done, Mary is constructing Rosa as the learner who knows the information and has the capacity to share it. That is also the case when repairing is used in conversation as the last move illustrated in Chart 2 shows. Rosa attempts a repair as there is miscommunication possibly because Lesly has a typo in her IM text.

All in all, with the discourse egalitarian knowledgeable learners I refer to language students who are aware of learning processes by reflecting on grammar issues and the story events. I also refer to language learners who display in the online talk their strategies to cope with unfamiliar words and misunderstandings constructing themselves as knowledgeable language learners or as found in the literature, students positioning as articulate knowers (Walkerdine, 1998; Castañeda-Peña, 2008a). What I find revealing in the present data is that although language learners expected to develop a higher academic status (Cohen, 1994) such a position was socially co-constructed and communally achieved. As it has been substantiated by the data, the research participants draw on discourses via the use of conversational strategies to locally construct such status. This is important to be noticed by English language teachers as some discourses might be used to hinder learning or they could possibly function otherwise as I argue below.

What I mean is that in fact language learners wanted to be recognized as learners who care about their language development but contrary to what was found in Walkerdine (1998) and Castañeda-Peña $(2008,2010)$ learners did not necessarily position as more intellectually superior than their own conversational partners. In such a way, language learners consolidated an atmosphere of understanding that permitted them to thrive in their language development through the online medium. Such finding can be 
best summarized in Nury's words when she said:

- "We all were in the same process of learning and with the same wish to do things well. This is why the important thing was to support mutually and understand that even if we made mistakes, at the end of this process all of us were going to learn from our mistakes and be successful in our learning of English" (Nury)

Achieving such a status of egalitarian knowledgeable learners was accomplished through face-saving moves, (Shin, 2006) by bringing about respectful and polite attitudes. In the research data, several conversations show that language learners do not put their conversational partners on the spot for making a mistake, nor do they seem to show self-sufficiency. On the contrary, they praise, show solidarity and respect. Such discursive strategies were, in some cases, also used to modify the output (Swain, 1985), extend or clarify turns and thus have more elaborated FL practice. This is substantiated in the data when research participants use attempts to repair, express solidarity and solicit help as demonstrated with the examples from Chart 2.

Furthermore, what I imply from the discourse of egalitarian-knowledgeable learners is that women learners invested in their language learning process as a result of the co-management of their power relationships. Norton (1995) has warned that "SLA theorists have not adequately explored how inequitable relations of power limit the opportunities L2 learners have to practice the target language outside classroom" (p. 12). This might mean that in some contexts, where English is the immigrants' second language, the native speakers have "power to impose reception" and many times immigrants' right to speak is unnoticed or as I conclude disrespected.

Indeed one of the language anecdotes that Norton (1995, p. 10) quotes is this one by Eva, an immigant :
"Everybody working with me is Canadian. When I started to work there, they couldn't

understand that it might be difficult for me to understand everything and know about everything what it's normal for them. To explain it more clearly I can write an example, which happened few days ago. The girl [Gail] which is working with me pointed at the man and said:

"Do you see him" -I said

"Yes, Why?"

"Don't you know him"?

"No I don't know him"

"How come you don't know him. Don't you watch TV. That's Bart Simpson

It made me feel so bad and I didn't answer her nothing. Until now I don't know why this person was important".

This excerpt demonstrates that Eva is silenced to some extent in that she cannot reply back when facing a threatening situation. She is linguistically undermined with strong social consequences as she feels separated from 'them'. Gail never made a learning opportunity available out of the Simpson situation. This is not the case in my research where the opposite situation appears to emerge. My research participants draw on discourses that make them equal as language learners even though power relationships mediate. I agree with Norton's (1995) argument when she claims that although everybody in the area of SLA acknowledges the importance of participating in communicative events for successful acquisition/ learning, many scholars take for granted that SL speakers choose under what circumstances they can communicate and that the native speakers regard the SL speakers as worth to be listened to -or let us say- cared for. As seen in the anecdote, the native speaker caused harm in Eva and positioned her unfavorably. 
If we are to compare this anecdote with the next pieces of talk (E.g. 2/discourse "Egalitarian Knowledgeable Learners") we can potentially learn a lot about the differences between SL socialization as opposed to FL socialization.

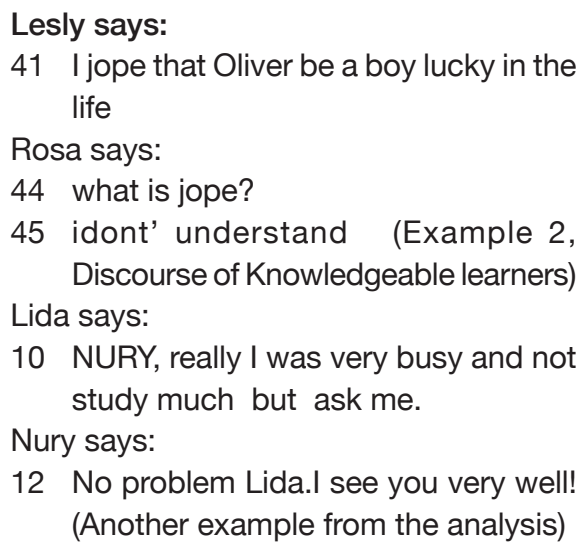

Through the analysis of the architectural organization of the talk, I discovered that in the foreign language context in which I carried out this research women-learners regard each other as worth to be listened and this may suggests that the co-management of the power relations make the language socialization process easier and not harmful for language learners as opposed to socialization in target countries where the native speaker exercises power over the immigrant limiting chances for target language use. This also opposes to what Castañeda-Peña (2008a, $2008 \mathrm{~b}, 2010$ ) has found in his research around girl-teachers in mixed sex and only-girls contexts of FL classroom interaction, in which little girls exercise power over their peers not allowing them to positioning favorably as "girl-teachers" and thus not being able to socialize in the FL.

What I just said also opens a window into the fact that language socialization might be easier in the foreign language setting because of the shared culture of the adult participants and the implicit cultural meanings that are collective. (Although this is something that clearly goes beyond the scope of this research and could be the interest of more systematic future research across diverse contexts). All in all, it is important to notice that my findings add up to the specialized literature (e.g. Norton, 1995, 2000) where language socialization happens in a second language environment. In such contexts, the interactional construction between speakers draws on discourses of power that make it difficult for one of the parties to socialize and learn the language. This also resonates with findings in foreign language contexts (e.g. Castañeda-Peña 2008a, 2008b, 2010). Looking at this across ages a hypothesis to be further tested is that in foreign language contexts, language socialization process might be easier in adult environments. This seems to be the case of my research with adult women. This also indicates that more research is needed across ages, contexts and levels of proficiency.

\section{References}

Albright, J., Purohit K., Walsh, C., (2002). Louise Rosenblatt seeks QtAznBoi@aol.com for LTR: Using chat rooms in internet. Journal of Adolescent \& Adult Literacy; 45, 8, pp 692-705.

Baxter, J (2002). Competing Discourses in the Classroom: A Post-structuralist Discourse Analysis of Girls' and Boys' Speech in Public Contexts. Discourse \& Society, 13, 6, 827-842.

Baxter, J. (2003). Positioning Discourse in Gender: A Feminist Methodology . Basingstoke: Palgrave Macmillan.

Benwell, B. \& Stokoe E. (2006) Discourse and Identity. Edinburgh: Edinburgh University Press.

Castañeda-Peña, H (2008a) Interwoven and Competing Gendered Discourses in a Preschool EFL Lesson in Harrington, K., Litosseliti, L., Sauntson, $\mathrm{H}$ and Sunderland, J (Eds) Gender and Language Research Methodology. London, Macmillan.

Castañeda-Peña, H. (2008b). Positioning Masculinities and Femininities in Preschool EFL education. Signo y Pensamiento, 53, 27, p. 314-326.

Castañeda-Peña, H. (2009). Masculinities and Feminities Go to Preeschool: Gender Positioning in Discourse. Bogotá: Editorial Pontificia Universidad Javeriana. 
Charles, A. (2008) From Bitmaps to Vector Graphics: Today's Multiliteracies. Journal of Maine Education, $24,2,17-21$

Cho, E \& Larke, P. (2010). Repair Strategies Usage of Primary Elementary ESL Students: Implications for ESL Teachers. The Electronic Journal for English as a Second Language, 14, 3, 1-18

Cohen, E. G (1994). Restructuring the Classroom: Conditions for Productive Small Groups. Review of Educational Research, 64, 1, 1-35.

Davies, B \& Harre, R. (1990). Positioning: The Discursive Production of Selves. Journal for the Theory of Social Behavior, 20, 43-63.

Doering, A., Miller, C., \& Veletsianos, G. (2008). Adventure Learning: Educational, Social, and Technological Affordances for Collaborative Hybrid Distance Education. Quarterly Review of Distance Education, 9, 3, 249-266.

Duff, P (1995). An Ethnography of Communication in Immersion Classrooms in Hungary. TESOL Quarterly, 29, 3, 505-536.

Fernández-García, M and Martínez-Arbelaiz, A (2002). Negotiation of Meaning in Nonnative Speaker-Nonnative Speaker Synchronous Discussions. CALICO Journal 19, 279-294.

Jacobs, G, E,. (2005). "ur Part of It": Portfolio People and Adolescent Use of Instant Messaging Doctoral Thesis, The Warner Graduate School of Education and Human Development, University of Rochester).

Jacobs, G (2008). People, purposes, and practices. Insights from cross-disciplinary research into instant messaging in D. Leu., Coiro, J., Knobel, M., Lankshear. (Eds) Handbook of Research on New Literacies. New York: Lawrence Erlbaum Associates.

Hampel, R., \& Hauck, M,. (2006). Computer-mediated Language Learning: Making Meaning in Multimodal Virtual Learning Spaces. The JALT CALL Journal, 2, 2, 3-18.

Hegedus, S \& Penuel, W. (2008). Studying New Forms of Participation and Identity in Mathematics Classrooms with Integrated Communication and Representational Infrastructures. Springer Science + Business Media B.V

Kawase, A., (2006). Second Language Acquisition and Synchronous Computer Mediated Communication Tesol \& Applied Linguistics, 6, 2, 1-27.

Kinzie, M. B., Whitaker, S. D., \& Hofer, M. J. (2005).
Instructional Uses of Instant Messaging (IM) During Classroom Lectures. Educational Technology \& Society, 8 2, 150-160.

Lam, W S E., (2004). Second Language Socialization in a Bilingual Chatroom, Global and Local Considerations. Language Learning \& Technology 8, 3, 44-65

Lam, W S E., (2009). Multiliteracies on Instant Messaging in Negotiating Local, Translocal, and Transnational Affiliations: A case of an Adolescent Immigrant. Reading Research Quarterly, 44, 4, 377-397.

Lang, R., \& Baron N. (2007). Text Messaging and IM. Linguistic Comparison of American College Data. Journal of Language and Social Psychology, 26, 3, 291-298.

Lewis, C \& Fabos, B. (2005). Instant messaging, Literacies, and Social Identities Reading Research Quarterly, 40, (4) 450-470.

Litosseliti, L. \& Sunderland, J. (2002). Gender Identity and Discourse Analysis. Philadelphia: John Benjamins Publishing.

Merriam, B. (1998) Qualitative Research and Case Study Applications in Education. San Francisco: JosseyBass.

Moore, L. (2008) Language Socialization and Second/ Foreign Language and Multilingual Education in Non-Western Settings in P. Duff and N. Hornberger (Eds) Encyclopedia of Language and Education, $2^{\text {nd }}$ Edition, Volume 8: Language Socialization, 175-185. London: Springer Science

Nakamura, I. (2008). Understanding how teacher and student talk with each other: An exploration of how 'repair' displays the co-management of talkin-interaction. Language Teaching Research 1, 2 p. 265-283.

Norton, B. (2000). Identity and Language Learning: Gender, Ethnicity, and Educational Change. London: Longman/Pearson Education.

Norton Pierce B. (1995). Social Identity, Investment, and Language Learning. TESOL Quarterly, 29, 1, 9-31.

McKinney, C., \& Norton, B. (2008). Identity in Language and Literacy Education. In B. Spolsky \& F. Hult (Eds.), The Handbook of Educational Linguistics. Oxford: Blackwell.

Merriam, B. (1998) Qualitative Research and Case Study Applications in Education. San Francisco: JosseyBass. 
Ochs, E. (1993). Constructing Social Identity: A Language Socialization Perspective. Research on Language and Social Interaction, 26, 3, 287-306.

Okuyama, Y (2005). Distance Language Learning via Synchronous Computer-Mediated Communication (SCMC): Eight Factors Affecting NS-NNS Chat Interaction. The JALT CALL Journal, 2005, 1, 2, 3-20.

Pavlenko A. (2002). Poststructuralist Approaches to the Study of Social Factors in Second Language Learning and Use in Cook, V. J. (Ed) Second Language Acquisition, 1 Portraits of the L2 User. Clevedon: Multilingual Matters Limited.

Pennycook, A. (2004). Critical Applied Linguistics. In A. Davies \& C. Elder (Eds), Handbook of Applied Linguistics. Blackwell: Oxford

Roberts, C. (2000). Language Acquisition or Language Socialization In and Through Discourse? Towards a Redefinition of the Domain of SLA in Mercer, N. \& Candlin, C. (Eds.), English Language Teaching in Its Social Context: A Reader.

Seedhouse, P. (2004) The Interactional Architecture of the Language Classroom: A Conversational Analysis Perspective. Oxford: Blackwell Publishing Inc.

Sinclair, J. \& Coulthard, R. (1975). Towards an analysis of discourse: the English used by teachers and pupils. Oxford: Oxford University Press.

Shin, D. (2006). ESL Students' Computer-mediated Communication Practices: Context and Configuration. Language Learning \& Technology, 10, 3, 65-84 retrieved from http://It.msu.edu/ vol10num3/shin/
Sunderland, J. (2006). Gender and Language: An Advanced Resource Book. London: Routledge.

Sunderland, J. (2004). Gendered Discourses. New York: Palgrave MacMillan.

Sunderland, J. (2002). Baby Entertainer, Bumbling Assistant and Line Manager. Discourses of Paternal Identity in Parentcraft Texts In Litosseliti, L. \& Sunderland, J. (Eds). Gender Identity and Discourse Analysis. (293-316) Philadelphia: John Benjamins Publishing.

Swain, M. (1985). Communicative competence: Some roles of comprehensible input and comprehensible output in its development. In S. Gass \& C. Madden (Eds.), Input in second language acquisition. Rowley, MA.: Newbury House.

Thiel, S. M. (2003). "Instant Identity: Girls, Adolescence and Negotiation of Identity in the New Culture of Instant Messaging”. New York: Peter Lang.

Toohey, K. (2001), 'Disputes in Child L2 Learning', TESOL Quarterly, 3, 27-279.

Weedon, Chris (1987) Feminist Practice and Poststructuralist Theory. Oxford: Basil Blackwell.

Wetherell, M. (1998). Positioning and Interpretative Repertoires: Conversation Analysis and Poststructuralism in Dialogue", Discourse and Society 9, 3, p. 431-456.

Willett, J. (1995), Becoming First Graders in an L2, An Ethnographic Study of L2 Socialization”. TESOL Quarterly 29, 3,473-503.

Wood, L \& Kroger, R. (2000) Doing Discourse Analysis: Methods for Studying Action in Talk and Text. London: Sage Publications. 